\title{
Sharia accounting perception according to MSMEs in East Java to foster a spirit of business continuity
}

\author{
D. Syariati, D.M. Putri*, S.F. Putri \& I.H. Al Siddiq \\ Universitas Negeri Malang, Malang, Indonesia \\ Mahirah \\ University of Malaysia, Kuala Terengganu, Malaysia
}

\begin{abstract}
The aim of this study is to determine whether sharia accounting can be understood and already practiced by MSMEs in East Java Province. This research is a qualitative study that examines the perceptions of sharia accounting in MSMEs, especially in East Java Province. The data was processed from the results of the online focus group discussion (FGD) studies with MSMEs owners. The result shows a positive perception of the owners of MSMEs on the implementation of Islamic accounting. Although MSME owners do not understand the principles of sharia accounting perfectly, they have started to carry out business as stated in sharia accounting. As Muslims, the owners of MSMEs understand sharia accounting can help them carry out buying and selling transactions according to the Al-Qur'an guidelines. Sharia accounting encourages MSME owners to maintain the quality and sustainability of the business.
\end{abstract}

Keywords: sharia accounting, MSME, business continuity.

\section{INTRODUCTION}

Indonesia has a high potential for the development of the Sharia industry. With the largest Muslim population, Indonesia has the potential to become the largest consumer and producer of Sharia, especially the halal business has received positive responses from various parties (Aziz \& Chok 2013; Battour et al. 2018; Haque et al. 2015; Latif et al. 2014; Mathew 2014; Rezai et al. 2012; Sadeeqa et al. 2013). Thomson Reuters (2018) released the value of spending on halal products in 2017 reached the US \$ 2.1 trillion and is estimated to increase to the US \$ 3 trillion in 2023. Interestingly, $10 \%$ of expenditures in that year were equivalent to Indonesia's spending on halal products (Indonesia Halal Lifestyle Center 2018). Halal food, halal fashion, media and recreation, Muslim friendly travel, halal pharmaceuticals, halal cosmetics, and Islamic finance are several opportunities that give benefits, especially for Micro Small and Medium Enterprises (MSMEs).

Strengthening MSMEs in the halal industry is one of the main strategies in the Indonesian Sharia economic master plan (Ministry of National Development Planning, 43). This is not surprising, considering that $60 \%$ of GDP comes from MSME (Micro Small Medium Enterprise) activities. The involvement of MSMEs in this industry has an impact on opportunities for increasing the growth of MSMEs and the halal climate in Indonesia. Responding to this, several MSMEs have positive perceptions of the halal business, including perceptions of non-bank Islamic financial institutions (Baumgartner \& Ebner 2010; Barokah \& Hanum 2013), crowdfunding sharia (Apriliani et al. 2019), and halal certification (Ahmad \& Anwar 2020). A positive perception indirectly emerges from the

*Corresponding author: dhika.maha.fe@um.ac.id 
emerging of Sharia business in Indonesia (Sofyan 2011). On the other hand, Islamic banking institutions' growth has received a negative perception from MSMEs because of the perceived similarity in nature between Islamic banking and conventional banking (Nugroho \& Tamala 2018).

If it is studied further, the management of sharia business is different from conventional business. The existence of divine elements is a milestone in business management, including financial management. From an accounting point of view, the use of Sharia accounting is relevant for entities involved in Islamic transactions. Sharia accounting offers different paradigms, principles, and characteristics than conventional accounting (DSAS IAI 2019). Sharia accounting use laws from Al-Quran, As-Sunah, Ijmak (ulamas agreement), and Qiyas (the similarity of certain events) as a guideline (Khaddafi et al. 2016). Siregar (2015) says that accounting principle according to Islam can be defined as a set of a basic legal and permanent standard, which taken from Islamic Sharia and used by accountants as the reference in doing their work, whether in the entry, analysis, measurement, exposure or explanation and become a reference in explaining certain events. Sharia accounting needs competent human resources in that field (Larasati \& Sumardi 2018). Sharia accounting is an alternative accounting. It is normatively conceptualized based on the Islamic principle that life is to return to God, which in Qur'anic term is expressed in an assertion of innaalillaahiwainnaailaihiraaji-uun (Triyuwono 2012).

In that case, brotherhood, justice, benefit, balance, and universalism are the principles carried out in the Sharia Financial Accounting Standards. The existence of this principle shows that business activities should aim for the benefit of a broader range. Not only worldly but also spiritual, not only material but also spiritual, not only individually but also collectively. In other words, Islamic accounting is oriented towards business continuity that emphasizes quality, not just profit. With regard to this, the number of Muslim entrepreneurs in Indonesia can become fertile ground for the implementation of sharia accounting to increase the going concern of MSMEs.

Unfortunately, the study about the perception of MSMEs towards sharia accounting has not been massively carried out. So far, studies on the perception of MSMEs have only been carried out on conventional accounting even though there is an enormous potential for the use of sharia accounting as a provision to enter the rapidly growing halal industry. On the other hand, MSMEs need to adjust to an increase in sharia transactions. In addition, the development of sharia accounting is also crucial for MSMEs because it can encourage a potential going concern on the continuity of MSME businesses. This study aims to examine the perception of the MSMEs which are owned or managed by Muslim entrepreneurs towards sharia accounting, especially in East Java Province. East Java Province was chosen because this province has the third larger MSMEs in Indonesia. This study is essential to complete the study of the practice of MSMEs sharia accounting. Moreover, this study's result can become one of the evaluation sources related to the implementation policy of Sharia accounting for MSMEs in Indonesia.

\section{METHODS}

This research is descriptive qualitative research. Some informants were chosen from each city in East Java and adjusted to the types of their businesses. There were 15 informants selected from the service, trade, and manufacture sectors. Types and sources of data used in this study include primary data and secondary data. Primary data was processed from the results of online focus group discussion (FGD) studies with Micro Small Medium Enterprise (MSMEs) owners. The FGD was conducted online because this research was carried out during the Covid-19 Pandemic. Secondary data in this study consisted of (a) government regulations regarding the MSMEs; (b) government regulations about sharia accounting; and (c) Al-Quran, As-Sunah, Ijmak. Secondary research data were obtained from the study of literature through search engines. Data analysis in this study used an interactive model. The components of the interactive model are (1) data collection, (2) data reduction, (3) data presentation, and (4) drawing conclusions. The data validation was carried out through triangulation of sources between data from MSMEs owners. 


\section{RESULTS AND DISCUSSION}

This research was conducted because MSMEs make a significant contribution to the Indonesian economy (Rukiah et al. 2019). Based on the Law of the Republic of Indonesia Number 20 of 2008 concerning Micro, Small, and Medium Enterprises (MSMEs), micro-enterprises are individual productive businesses and/or individual businesses that meet the law's criteria. As described in the law, a small business is a productive business carried out by individuals or business entities. Then, medium-sized enterprises are productive economic enterprises carried out by individuals or business entities with total net assets or annual sales proceeds that meet the law's criteria. Meanwhile, large enterprises are economic enterprises carried out by business entities with a net worth, or annual sales proceeds greater than medium enterprises.

The presence of MSMEs becomes essential for the wheels of the country's economy because MSMEs are a form of business that can provide jobs. Besides, MSMEs' activities can expand employment opportunities and provide broad economic services to the community. MSMEs play an important role in encouraging economic growth, increasing public income equality, and realizing national stability. Indonesian MSMEs contribute significantly to gross domestic product (GDP). Based on the data from the Ministry of Cooperatives, Small and Medium Enterprises (2010-2018), Indonesian MSMEs contributed up to IDR 8,573.9 trillion to Indonesia's GDP (based on current prices) in 2018. Indonesia's GDP in 2018 was IDR 14,838.3 trillion, so the contribution of MSMEs reached $57.8 \%$ of GDP. In addition, MSMEs employ $116,978,631$ people or $97 \%$ of the total Indonesian workforce (MSMEs and Large Units). There are 64,194,057 MSMEs in Indonesia or $99.99 \%$ of the total business units in Indonesia.

A large number of MSMEs in Indonesia is accompanied by the fact that Indonesia is a country with the largest number of Muslims in the world, which further strengthens the development of the sharia industry. In this case, the presence of sharia accounting is an answer to the demands related to recording transactions in accordance with the Al-Quran, As-Sunah, Ijmak (ulamas agreement), and Qiyas (the similarity of certain events) as a guideline. Based on the research results, it is known that there are positive perceptions of the owners of MSMEs towards the implementation of sharia accounting. Even though MSMEs owners do not understand the principles of sharia accounting comprehensively, they have started to carry out their business procedure according to sharia accounting. That procedure includes (a) staying away from usury; (b) set aside zakat for each business's revenues, and; (c) transact with a clear contract with the buyer. As Muslims, the owners of MSMEs are well aware that sharia accounting can help them carry out buying and selling transactions according to the Al-Qur'an guidelines.

In its development, MSMEs have strong resilience in facing an economic crisis. But in its management, MSMEs are constrained on the aspects of management and finance, such as the less quality of human resources who cannot record or bookkeeping the financial condition. Therefore, MSMEs owners really hope that there will be sharia accounting training for daily buying and selling transactions. In addition, MSME owners also expect technical guidelines for buying and selling transactions using sharia accounting principles. The guidelines are containing rules and examples of MSMEs transactions presented in the Islamic accounting standard. These guidelines also explain the terms in Islamic accounting and the time of their use. As a complement, sharia accounting guidelines specifically for MSMEs also contain verses of the Qur'an related to transactions that occur. This guideline is expected to be a window of knowledge and information for MSMEs related to Islamic accounting's comprehensive implementation. In addition, this guideline will also be socialized to MSMEs using regular training and assistance both online and offline. With this assistance, MSMEs will be guided to understand and practice the contents of the guidelines. Through this preparation and assistance, it is expected that MSMEs can improve the quality of financial management through sharia accounting that is oriented towards divine values. Sharia financial reporting applications not only focus on applications that are free of usury or gambling (speculation). More than that, it is expected to provide benefits for the community, especially for MSMEs. With the main values of Islam, shariah accounting aims for justice, holistic welfare, and benefit for all people. 
Therefore, the financial report records information about a company in the accounting period that summarizes the company's financial performance. Financial reports are useful for stakeholders in analyzing and interpreting financial performance and the company's condition (IAI 2016). In general, the purpose of both conventional and Sharia financial reports is to present financial reports. However, sharia accounting juxtaposes accounting science with the values contained in the Al-Quran, As-Sunah, Ijmak (ulamas agreement), and Qiyas (the similarity of certain events). During the reign of Caliph Umar bin Khattab, accounting known as an alamel, mubashar, al$k a t e b$, the person responsible for recording and reporting financial and non-financial information. Especially for an accountant by the name Muhasabah or Muhtasib (Nurhayati 2009). Syahatah (2001) formulated the six purpose of muhasabah (accounting) in Islam, namely maintaining the property (hifz al-amwal), the existence of al-kitabah when there is a dispute, can help in drawing conclusions, determine the results of the business to be deliberate, determine and calculate the rights of the union in business and determine, reward, reply or sanction. Syafrida Hani et al. (2018) said the purpose of sharia financial reports is to provide information concerning the financial position, performance, and changes in the financial position of an Islamic entity that is useful for a large number of users in making economic decisions and other objectives. Those purposes are described below.

a. Improve compliance with sharia principles in every transaction and business activity.

b. Provide information on the compliance of Islamic entities with sharia principles as well as information on assets, liabilities, income, and expenses that are not in accordance with sharia principles.

c. Information to help evaluate the fulfillment of the entity's and sharia's responsibilities towards the trust in securing funds, investing them at a reasonable profit level.

d. Information regarding investment returns obtained by investors and owners of temporary funds and information regarding the fulfillment of obligations. The social function of Islamic entities, including the management and distribution of zakat, infaq, alms, and waqf.

Sharia Accounting is the science of accounting or accountability of all assets and economic activities of an individual business or group or company following the Qur'an and As-Sunnah to achieve true wealth or prosperity or 'Falah' (Choudhury 2005). The objective of implementing sharia accounting is to achieve socio-economic justice and carry out our worship in fulfilling our obligations to Allah SWT. It is also a form of our responsibility for individual duties in reporting all matters relating to financial reports. Sharia accounting techniques is resulted from accurate accounting information to calculate zakat and accountability horizontally to Allah SWT based on morals, faith, and piety.

In accordance with the description above, the Islamic nuances caused by the implementation of sharia accounting can affect the way MSME owners conduct business. MSME owners feel that sharia accounting can help them keep their business away from things that are not following religious teachings. Thus, MSMEs owners feel calmer in life because they work not only for money but also for the pleasure of Allah. In addition, with the existence of sharia accounting practices, every incoming and outgoing transaction is strictly maintained. Sharia accounting indirectly encourages MSME players to maintain their business quality, from the financial perspective, production to services. Sharia accounting can inspire someone, to be honest, and trustworthy. By adhering to quality, honesty, and trust, a business entity's sustainability can be maintained properly.

The feeling of calm arising from the integration of divine values with knowledge through sharia accounting can be called a part of celestial management. Putri (2020) said that celestial management is a management science based on the interpretation of spiritual values and principles derived from the word of Allah to be implemented in life. It is the belief that work is part of worship. Work is not only related horizontally to humans but also vertically upwards to the Allah SWT. Through celestial management, MSMEs owners can conduct continuous improvement for their organizations. However, business is not just a matter of material but also a missionary field that can reassure us. 


\section{CONCLUSION}

In accordance with the description above, the Islamic nuances caused by the implementation of sharia accounting can affect the way MSMEs owners conduct business. MSMEs owners feel that sharia accounting can help them keep their business away from things that are not following religious values. Thus, MSMEs owners feel calmer in life because they work not only for money but also for Allah's pleasure. With the existence of sharia accounting practices, every incoming and outgoing transaction is strictly maintained. Sharia accounting indirectly encourages MSME players to maintain the quality of their business. By adhering to quality honesty and trust, a business entity's sustainability can be maintained properly. The importance of MSMEs' existence is especially evident during the critical economic times after the Covid-19 pandemic. MSMEs is a sector that can maintain the stability of people's income. Business management that juxtaposes knowledge with faith in Allah, is an effort to survive critical times without violating ethics.

\section{REFERENCES}

Ahmad, B., \& Anwar, M. K. 2020. Analisis Respon Perilaku Usaha Minuman Kopi (Coffe Shop) Terhadap Kewajiban Sertifikasi Halal. Jurnal Ekonomika Dan Bisnis Islam, 3(2).

Apriliani, R., Ayunda, A., \& Fathurochman, S. F. 2019. Kesadaran Dan Persepsi Usaha Mikro Dan Kecil Terhadap Crowdfunding Syariah. Amwaluna: Jurnal Ekonomi Dan Keuangan Syariah, 3(2), 267-389.

Aziz, Y. A., \& Chok, N. V. 2013. The Role Of Halal Awareness, Halal Certification, And Marketing Components In Determining Halal Purchase Intention Among Non-Muslims In Malaysia: A Structural Equation Modeling Approach. Journal Of International Food \& Agribusiness Marketing, 25(1), 1-23.

Barokah, S., \& Hanum, A. N. 2013. Analisis Presepsi Nasabah Dan Perkembangan Umkm Setelah Memperolah Pembiayaan Mudharabah (Studi Kasus Bprs Binama Kota Semarang). Maksimum, 3(2).

Battour, M., Hakimian, F., Ismail, M., \& Boğan, E. 2018. The Perception Of Non-Muslim Tourists Towards Halal Tourism. Journal Of Islamic Marketing. 4(1), 15-25.

Baumgartner, R. J., \& Ebner, D. 2010. Corporate Sustainability Strategies: Sustainability Profiles And Maturity Levels. Sustainable Development, 18(2), 76-89. Https://Doi.Org/10.1002/Sd.447

Choudhury, M. A. 2005. Islamic Economics And Finance: Where Do They Stand? The Islamic Quarterly, 49(4), 247-280.

Haque, A., Sarwar, A., Yasmin, F., Tarofder, A. K., \& Hossain, M. A. 2015. Non-Muslim Consumers' Perception Toward Purchasing Halal Food Products In Malaysia. Journal Of Islamic Marketing. 4(1), 15-25.

Khaddafi, M., Siregar, S., Harmain, H., Nurlaila, Zaki, M., \& Dahrani. 2016. Akuntansi Syariah Meletakkan Nilai-Nilai Syariah Islam Dalam Ilmu Akuntansi (A. Ikhsan (Ed.); 1st Ed.). Penerbit Madenatera.

Larasati, M., \& Sumardi. 2018. Pelatihan Akuntansi Lembaga Keungan Syariah Bagi Siswa Di Smk Plus Ashabulyamin Kabupaten Cianjur. Jurnal Inovasi Sosial \& Pengabdian Kepada Masyarakat, 1(2), 168-177. Https://Doi.Org/10.22236/Syukur

Latif, I. A., Mohamed, Z., Sharifuddin, J., Abdullah, A. M., \& Ismail, M. M. 2014. A Comparative Analysis Of Global Halal Certification Requirements. Journal Of Food Products Marketing, 20(Sup1), 85-101.

Mathew, V. N. 2014. Acceptance On Halal Food Among Non-Muslim Consumers. Procedia-Social And Behavioral Sciences, 121, 262-271.

Nugroho, L., \& Tamala, D. 2018. Persepsi Pengusaha Umkm Terhadap Peran Bank Syariah. Jurnal Sikap (Sistem Informasi, Keuangan, Auditing Dan Perpajakan), 3(1), 49-62.

Nurhayati, S. 2009. Akuntansi Syariah Di Indonesia. Penerbit Salemba.

Putri, D. M. 2020. Efforts To Realize Halal Business: Implementation Of Celestial Management In Msmes. Kne Social Sciences, 2020, 185-195. Https://Doi.Org/10.18502/Kss.V4i9.7325

Rezai, G., Mohamed, Z., \& Shamsudin, M. N. 2012. Non-Muslim Consumers' Understanding Of Halal Principles In Malaysia. Journal Of Islamic Marketing.

Rukiah, Nuruddin, A., \& Siregar, S. 2019. Islamic Human Development Index Di Indonesia (Suatu Pendekatan Maqhasid Syariah ). Istinbáth, 18(2), 307-327. 
Sadeeqa, S., Sarriff, A., Masood, I., Farooqi, M., \& Atif, M. 2013. Evaluation Of Knowledge, Attitude, And Perception Regarding Halal Pharmaceuticals, Among General Medical Practitioners In Malaysia. Archives Of Pharmacy Practice, 4(4).

Sofyan, R. 2011. Bisnis Syariah, Mengapa Tidak?: Pengalaman Penerapan Pada Bisnis Hotel. Gramedia Pustaka Utama.

Syahatah, H. 2001. Pokok-Pokok Pikiran Akuntansi Islam. Terj. Khusnul Fatarib. Jakarta: Akbar Media Eka Sarana.

Triyuwono, I. 2012. Akuntansi Syariah: Perspektif, Metodologi Dan Teori Pt Rajagrafindo Persada. Jakarta. 